\title{
The use of glycoinformatics in glycochemistry
}

Thomas Lütteke

\author{
Review \\ Address: \\ Justus-Liebig-University Gießen, Institute of Veterinary Physiology \\ and Biochemistry, Frankfurter Str. 100, 35392 Gießen, Germany

\section{Email:} \\ Thomas Lütteke - thomas.luetteke@vetmed.uni-giessen.de \\ Keywords: \\ carbohydrates; databases; glycomics; software
}

Beilstein J. Org. Chem. 2012, 8, 915-929.

doi:10.3762/bjoc.8.104

Received: 07 March 2012

Accepted: 29 May 2012

Published: 21 June 2012

This article is part of the Thematic Series "Synthesis in the glycosciences II".

Guest Editor: T. K. Lindhorst

(C) 2012 Lütteke; licensee Beilstein-Institut.

License and terms: see end of document.

\begin{abstract}
Glycoinformatics is a small but growing branch of bioinformatics and chemoinformatics. Various resources are now available that can be of use to glycobiologists, but also to chemists who work on the synthesis or analysis of carbohydrates. This article gives an overview of existing glyco-specific databases and tools, with a focus on their application to glycochemistry: Databases can provide information on candidate glycan structures for synthesis, or on glyco-enzymes that can be used to synthesize carbohydrates. Statistical analyses of glycan databases help to plan glycan synthesis experiments. 3D-Structural data of protein-carbohydrate complexes are used in targeted drug design, and tools to support glycan structure analysis aid with quality control. Specific problems of glycoinformatics compared to bioinformatics for genomics or proteomics, especially concerning integration and long-term maintenance of the existing glycan databases, are also discussed.
\end{abstract}

\section{Introduction}

Carbohydrates, often referred to as glycans, differ from other biopolymers such as proteins or nucleic acids in various ways. The number of different monosaccharides that are present in naturally occurring glycans is significantly higher than the number of proteogenic amino acids, or of nucleotides that form DNA or RNA strands [1,2]. Furthermore, the monosaccharides can be linked to each other in several ways, including the possibility to form branched structures. Another important difference between glycans, on the one hand, and proteins and nucleic acids, on the other hand, is visible in their biosynthesis:
DNA, RNA and proteins are synthesized by copying, transcription or translation, respectively, of nucleic acids, whereas carbohydrates are built in a non-template-driven approach by the sequential action of various glycosyltransferases (GT) that add monosaccharides to an existing glycan chain, and by glycoside hydrolases (GH) that remove specific monosaccharides [3]. For this reason there is no technique available to amplify carbohydrates comparable to Polymerase Chain Reaction (PCR) or protein expression systems. Instead, carbohydrates have to be analyzed in physiological amounts. If specific and well-defined 
glycans are required for experiments such as glycan arrays [4], they have to be synthesized chemically [5].

The special features of carbohydrates not only pose problems for their wet-lab analysis but also for computational approaches that deal with carbohydrates. Classical bioinformatics algorithms are developed for linear gene or protein sequences, and thus cannot be applied to branched carbohydrates. Instead, new algorithms that deal with the branching as well as with other special features of carbohydrates, such as microheterogeneity, have to be developed [6,7]. Furthermore, there are much less primary data on carbohydrates available than, e.g., on proteins, to test or train the algorithms [8]. For these reasons, glycoinformatics as a research area at the intersection of bioinformatics and chemoinformatics has been considered to be lagging behind its sister fields, such as bioinformatics for genomics or proteomics, for a long time. By now, however, glycoinformatics is coming of age and offers a variety of databases and applications that are of use to glycoscientists. Many new resources are still being developed, and efforts for a better integration of existing resources have also been started. Formats and protocols for data exchange have been specified $[9,10]$. Recently, the MIRAGE (Minimum Information Related to A Glycomics Experiment) consortium was founded to define checklists for the standardization of experimental glycomics data and meta information [11]. However, there is still no longterm repository of glycan structures available.

Being part of the Thematic Series "Synthesis in the glycosciences II", this overview mainly focuses on those resources that are relevant to glycan synthesis. For a more general overview of glycoinformatics resources and the development of the field over time, the reader is referred to references [12-17].

\section{Review \\ Carbohydrate databases Glycan structure databases}

Various databases that collect information on carbohydrates are now available (Table 1) and new resources are still being developed. The individual databases differ in the kind of data that are stored, the number and topicality of entries, the search interfaces, and the way the data are presented to the user. They are of use to glycochemists in several ways. First of all, they provide literature references on specific carbohydrate structures, which are often difficult to find via keyword searches in general literature databases such as PubMed. However, keeping databases up to date with bibliographic references is a timeconsuming task that cannot be performed automatically by computer programs because the glycan structures are often encoded graphically within the publication figures. And even when information on glycan chains is given in the text, the nota- tion is often complex, difficult to parse, and may contain ambiguities. Therefore, database users should keep in mind that if a database does not list any reference that, e.g., deals with the synthesis of a specific glycan structure, it does not mean that there is no such reference available: it just might not have been included into the database yet. Aside from providing literature references, carbohydrate databases can also serve glycochemists as a source of information on structures that are potential targets for synthesis. For this purpose resources that feature data such as the biological source, or diseases related to a glycan structure, can be of special interest.

The first approach used to create a comprehensive collection of carbohydrate data that had been published in scientific literature, was the Complex Carbohydrate Structure Database (CCSDB) [19], which is often referred to by the name of its querying software, CarbBank [20]. Each CarbBank entry contains a glycan structure together with a bibliographic reference, and further information such as taxonomic data of the biological source, experimental methods, or related diseases are also present. When funding stopped in the mid-1990s, however, CarbBank was no longer updated and CCSDB no longer maintained. Nevertheless, its content formed the basis of several other databases that were subsequently developed. Depending on their focus, other resources have incorporated all or part of the CarbBank data, and have added further information. The Bacterial Carbohydrate Structure Database (BCSDB), for example, has incorporated ca. 4000 CarbBank entries, the structures of which are of bacterial origin, and added ca. 5000 records referring to articles that were published after the maintenance of CarbBank had stopped. BCSDB covers more than $90 \%$ of the literature in the scope of bacterial carbohydrates [18]. Data that are listed in the entries include bibliographic data, taxonomic information on the biological source, and primary data of nuclear magnetic resonance (NMR) experiments that had been performed to elucidate the structures. Other sources of NMR data are SugaBase [36], which similar to CarbBank is no longer maintained, GlycoBase (Lille), Escherichia coli O-antigen Database (ECODAB) [22], and Glycosciences.DB [31], the database of the Glycosciences.de web portal. Glycosciences.DB, formerly known as SweetDB [38], started to make CarbBank entries available over the internet and to provide 3D structural models of the glycan structures. These models are calculated by the Sweet-2 software [39]. NMR data were incorporated from SugaBase or manually entered from the literature. Glycosciences.DB also contains information on carbohydrate $3 \mathrm{D}$ structures that are available in the Protein Data Bank (PDB, [40]). Extraction and validation of carbohydrate data from PDB entries is automated to a large extent and therefore requires only minimal human interference [41], making the update of these data much less dependent of 
Table 1: Carbohydrate structure databases.

\begin{tabular}{|c|c|c|c|}
\hline Name, Ref & Main content, comments & URL & Status ${ }^{a}$ \\
\hline $\begin{array}{l}\text { BCSDB (Bacterial } \\
\text { Carbohydrate Structure } \\
\text { Database) [18] }\end{array}$ & $\begin{array}{l}\text { Glycan sequences, taxonomy, bibliography, } \\
\text { NMR data }\end{array}$ & http://csdb.glycoscience.ru/bacterial/ & $\mathrm{D} / \mathrm{M}$ \\
\hline CCSDB//CarbBank $[19,20]$ & Glycan sequences, taxonomy, bibliography & - & $\mathrm{S}$ \\
\hline $\begin{array}{l}\text { CFG Glycan Structure DB } \\
\text { [21] }\end{array}$ & $\begin{array}{l}\text { Glycan sequences, taxonomy, bibliography, } \\
\text { glycan array data }\end{array}$ & $\frac{\text { http://www.functionalglycomics.org/glyco }}{\text { mics/molecule/jsp/carbohydrate/carbMol }}$ & S \\
\hline $\begin{array}{l}\text { ECODAB (Escherichia coli } \\
\text { O-antigen Database) }[22,23]\end{array}$ & $\begin{array}{l}\text { Glycan sequences, NMR data, } \\
\text { glycosyltranferases ( } E \text {. coli glycans only) }\end{array}$ & http://www.casper.organ.su.se/ECODAB/ & $\mathrm{D} / \mathrm{M}$ \\
\hline EUROCarbDB [24] & $\begin{array}{l}\text { Glycan sequences, taxonomy, bibliography, } \\
\text { MS data }\end{array}$ & http://www.ebi.ac.uk/eurocarb/ & $\mathrm{S}$ \\
\hline Glycobase (Dublin) [25] & $\begin{array}{l}\text { Glycan sequences, taxonomy, HPLC data, } \\
\text { MS data, bibliography }\end{array}$ & $\frac{\text { http://glycobase.nibrt.ie }}{\text { (registration required) }}$ & $\mathrm{D} / \mathrm{M}$ \\
\hline Glycobase (Lille) & Glycan sequences, taxonomy, NMR data & http://glycobase.univ-lille1.fr/base/ & $?$ \\
\hline GlycoconjugateDB [26] & Glycan sequences, PDB references & http://www.glycostructures.jp & $?$ \\
\hline GlycoMapsDB [27] & Computed conformational maps & $\begin{array}{l}\text { http://www.glycosciences.de/modeling/gl } \\
\text { ycomapsdb/ }\end{array}$ & $\mathrm{P}$ \\
\hline GlycoNavi (JCGGDB) & $\begin{array}{l}\text { Chemical reactions of carbohydrate } \\
\text { molecules }\end{array}$ & http://ws.glyconavi.org & $\mathrm{D} / \mathrm{M}$ \\
\hline GlycomeDB [28-30] & $\begin{array}{l}\text { Glycan sequences and taxonomic data } \\
\text { extracted from other databases }\end{array}$ & http://www.glycome-db.org & $\mathrm{D} / \mathrm{M}$ \\
\hline $\begin{array}{l}\text { GlycoPOD (JCGGDB } \\
\text { GlycoProtocols Online } \\
\text { Database) }\end{array}$ & $\begin{array}{l}\text { Protocols for synthesis and analysis of } \\
\text { glycan structures }\end{array}$ & $\begin{array}{l}\text { http://jcggdb.jp/GlycoPOD/protocolListSh } \\
\text { ow.action }\end{array}$ & $\mathrm{D} / \mathrm{M}$ \\
\hline Glycosciences.DB [31] & $\begin{array}{l}\text { Glycan sequences, taxonomy, bibliography, } \\
\text { 3D structure models, NMR data, PDB } \\
\text { references }\end{array}$ & http://www.glycosciences.de/database/ & $\mathrm{D} / \mathrm{M}$ \\
\hline GlycosideDB (JCGGDB) & $\begin{array}{l}\text { Chemical structures of glycoconjugates, } \\
\text { aglycones }\end{array}$ & http://jcggdb.jp/search/GlycosideDB.cgi & $\mathrm{D} / \mathrm{M}$ \\
\hline GlycoSuiteDB $[32,33]$ & $\begin{array}{l}\text { Glycan sequences, taxonomy, bibliography, } \\
\text { disease, protein glycosylation sites }\end{array}$ & http://glycosuitedb.expasy.org & $\mathrm{D} / \mathrm{M}$ \\
\hline JCGGDB [34] & $\begin{array}{l}\text { Collection of several Japanese glyco-related } \\
\text { databases }\end{array}$ & http://jcggdb.jp/index_en.html & $\mathrm{D} / \mathrm{M}$ \\
\hline KEGG GLYCAN [35] & $\begin{array}{l}\text { Glycan sequences, bibliography, } \\
\text { cross-references to other KEGG resources }\end{array}$ & http://www.genome.jp/kegg/glycan/ & $?$ \\
\hline MonosaccharideDB & Monosaccharide notation and properties & http://www.monosaccharidedb.org & $\mathrm{D} / \mathrm{M}$ \\
\hline SugaBase [36] & Glycan sequences, taxonomy, NMR data & - & S \\
\hline UniCarb-DB [37] & Glycan sequences, taxonomy, LC-MS data & http://www.unicarb-db.com & $\mathrm{D} / \mathrm{M}$ \\
\hline
\end{tabular}

aD/M: Database is further developed and/or maintained; P: Development/maintenance is paused, but planned to be continued; S: Development/maintenance is stopped (or, in the case of CFG resources, will be stopped soon because funding will discontinue); ?: Status unknown.

funding than that of data extracted from the literature. Carbohydrate data from the PDB are also available in the Glycoconjugate Database [26], but updates are less frequent than in Glycosciences.DB, which is updated weekly with new PDB entries.

Other databases that implemented CarbBank data are KEGG GLYCAN [35], EUROCarbDB [24], and the Glycan Structure Database of the Consortium for Functional Glycomics (CFG) [21]. KEGG GLYCAN is part of the Kyoto Encyclopedia of Genes and Genomes (KEGG) and integrates carbohydrate data with a variety of tools and information on other biomolecules. The KEGG portal has a particular focus on biosynthetic path- ways. EUROCarbDB was developed to store primary data of mass spectrometry (MS), NMR and high performance liquid chromatography (HPLC) experiments. In addition to data imported from CarbBank, the database contains structures from such experiments (mainly MS data). Detailed information on the biological context in which a structure was found, is also provided. EUROCarbDB is another example of a database that is no longer being developed because the funding has stopped. However, it was developed as an open-source project. Therefore, newly funded projects such as UniCarb-DB [37] or the latest version of GlycoBase (Dublin) [25], which stores HPLC data, are able to make use of the EUROCarbDB source code 
and, thus, the software does not need to be rewritten. The CFG databases are focused on various aspects of mammalian glycans. Similar to EUROCarbDB, the CFG Glycan Structure Database features CarbBank $N$ - and $O$-glycan data as well as entries that have been found in MS experiments performed by CFG members or that have been synthesized by the CFG. The database is complemented with glycans from the GlycoMinds Ltd. seed database. Primary data of MS experiments and glycan array screens are also available via the CFG website. If a glycan structure has been detected to be bound by a glycan-binding protein in a CFG glycan array experiment, links to the corresponding protein pages are provided with the glycan structure entries. A link to a 3D structural model generated by the GLYCAM-Web Biomolecule Builder [42] is also given. GlycoSuiteDB $[32,33]$, which started as a commercial database and was later made publicly accessible, differs from most other carbohydrate databases in that it provides information on proteins to which specific glycans were found to be attached, including details on glycosylation sites.

The Japan Consortium for Glycobiology and Glycotechnology DataBase (JCGGDB) [34] provides a collection of individual databases that are cross-linked with each other and currently being actively developed. Unfortunately, some resources are not fully translated to English yet, but nevertheless the portal contains various useful databases. Of those, GlycoPOD is of particular use for wet-lab scientists. GlycoPOD is a collection of lab protocols for the synthesis or analysis of carbohydrates and other glyco-related experiments. The protocols include step-by-step instructions, references, and features to rate the protocols or to post related questions. Another resource with a special focus on glycochemistry is GlycoNavi, which is a database of chemical reactions that involve carbohydrates and of the molecules involved in these reactions. Information about the chemical properties of carbohydrate molecules can also be found in general molecule databases, such as ChEBI (Chemical Entities of Biological Interest, http://www.ebi.ac.uk/chebi/) [43,44] or PubChem (http://pubchem.ncbi.nlm.nih.gov) [45]. These resources provide data that are important for chemists but are often not present in the more biology-focused carbohydratespecific databases, such as atomic descriptions, charges, chemical synonyms, SMILES (Simplified Molecular Input Line Entry System) and InChi (IUPAC International Chemical Identifier) codes, and 3D structural information in mol2 format. However, no carbohydrate-specific search options are available. This can make it difficult to locate entries in ChEBI or PubChem especially for oligosaccharides. Introducing crosslinks between carbohydrate-specific databases and the major chemical databases would not only make it easier to find specific carbohydrates, but also provide a linkage between biological and chemical information.

\section{Databases on glycosyltransferases and glycan binding proteins}

As an alternative or complement to chemical synthesis it is possible to make use of the enzymes that build or degrade the glycan chains in vivo, the glycosyltransferases or glycoside hydrolases, respectively [46-49]. To plan such experiments, however, detailed knowledge of the substrate-specificity of these enzymes is required. The same applies to glycan-binding proteins, which can be promising targets for the synthesis of glycomimetics. To some extent, knowledge of such proteins can of course be found in classical protein or enzyme databases, such as UniProt (http://www.uniprot.org) [50] or BRENDA (http://www.brenda-enzymes.info) [51]. However, these databases do not offer any glyco-specific search options. Therefore, it can be difficult to find the respective data in these general databases. There are various resources available that specifically deal with glyco-enzymes or glycan-binding proteins (Table 2). These are often much better suited as starting points for searching than the more general protein databases, not only because of the more narrow focus, but also because most of the glyco-specific protein databases contain links to corresponding entries in the more general databases, but usually not vice versa.

A major resource for glyco-enzymes (glycosyltransferases, glycoside hydrolases, polysaccharide lyases and carbohydrate esterases) as well as proteins that feature carbohydrate-binding modules is CAZy (Carbohydrate Active Enzymes). This database classifies proteins by sequence comparison and clusters them into families by using well-established bioinformatics tools such as BLAST [55] or HMMER [56]. In this way, approximately $1-3 \%$ of the proteins encoded by a typical genome are categorized as glyconzymes [52,57]. For each CAZy family, the corresponding proteins are listed (and can be filtered by subcategories, such as taxonomic kingdoms or entries with existing 3D structural information) together with links to corresponding entries in NCBI GenBank, UniProt [50] or PDB [40]. However, little information is provided about enzyme specificity, kinetics, or catalytic residues, which is crucial information if the enzymes are to be used in carbohydrate synthesis experiments. Such information can be obtained together with literature references from CAZy's sister resource CAZypedia, a wiki on glyco-enzymes.

Glyco-enzyme data are also found in KEGG Pathway and KEGG Orthology. These resources are not glyco-specific, but metabolic pathways are classified in a hierarchical system, which makes it easy to locate the glyco-related data, but also to learn about the relations between carbohydrate metabolism and other metabolic pathways. KEGG resources cover a diverse range of species of all kingdoms. In contrast, CFG GT database focuses on mammalian glycosyltransferases, and GT informa- 
Table 2: Glycosyltransferase/glycan-binding protein databases.

Name, Ref

Main content, comments

URL

Status $^{a}$

\section{Glycosyltransferase (GT) databases}

\begin{tabular}{|c|c|c|c|}
\hline $\begin{array}{l}\text { CAZy (Carbohydrate Active } \\
\text { enZYmes) [52] }\end{array}$ & $\begin{array}{l}\text { Glyco-enzymes clustered into families by } \\
\text { sequence comparison }\end{array}$ & http://www.cazy.org & $\mathrm{D} / \mathrm{M}$ \\
\hline CAZyPedia & $\begin{array}{l}\text { Wikipedia-like description of GT and GH } \\
\text { families }\end{array}$ & http://www.cazypedia.org & $\mathrm{D} / \mathrm{M}$ \\
\hline CFG GT DB & $\begin{array}{l}\text { Enzymes for biosynthesis of mammalian } \\
\text { glycans }\end{array}$ & $\begin{array}{l}\frac{\text { http://www.functionalglycomics.org/glyco }}{\text { mics/molecule/jsp/glycoEnzyme/geMolec }} \\
\underline{\text { ule.jsp }}\end{array}$ & S \\
\hline GlycoGeneDB (JCGGDB) & $\begin{array}{l}\text { Glyco-enzymes: genes, substrates, gene } \\
\text { expression }\end{array}$ & http://riodb.ibase.aist.go.jp/rcmg/ggdb/ & $\mathrm{D} / \mathrm{M}$ \\
\hline GPI Biosynthesis report [53] & $\begin{array}{l}\text { Enzymes involved in biosynthesis of glycosyl } \\
\text { phosphatidyl inositol (GPI) anchors }\end{array}$ & $\frac{\text { http://mendel.imp.ac.at/SEQUENCES/gpi }}{\text {-biosynthesis/ }}$ & S \\
\hline KEGG Pathway & $\begin{array}{l}\text { Biosynthesis pathways, enzyme entries with } \\
\text { sequence and notation data and links to } \\
\text { other resources }\end{array}$ & http://www.genome.jp/kegg/pathway.html & $\mathrm{D} / \mathrm{M}$ \\
\hline KEGG Orthology & $\begin{array}{l}\text { General data on enzymes and catalyzed } \\
\text { reactions, links to specific proteins }\end{array}$ & http://www.genome.jp/kegg/ko.html & $\mathrm{D} / \mathrm{M}$ \\
\hline \multicolumn{4}{|c|}{ Glycan binding proteins (GBP) databases } \\
\hline CFG Glycan Binding Proteins & $\begin{array}{l}\text { Includes information on recognized glycan } \\
\text { epitopes and on related diseases }\end{array}$ & $\begin{array}{l}\text { http://www.functionalglycomics.org/glyco } \\
\text { mics/molecule/jsp/gbpMolecule-home.jsp }\end{array}$ & S \\
\hline $\begin{array}{l}\text { Genomics Resource for } \\
\text { Animal Lectins }\end{array}$ & Description of animal lectin families & $\begin{array}{l}\text { http://www.imperial.ac.uk/research/anima } \\
\underline{\text { lectins/ }}\end{array}$ & S \\
\hline GlyAffinity & $\begin{array}{l}\text { Collection of glycan array data from several } \\
\text { resources }\end{array}$ & $\underline{\text { http://worm.mpi-cbg.de/affinity/ }}$ & S \\
\hline GlycoEpitopeDB [54] & $\begin{array}{l}\text { Antibodies that bind to carbohydrates, } \\
\text { glyco-epitopes recognized by the antibodies }\end{array}$ & http://www.glyco.is.ritsumei.ac.jp/epitope/ & $\mathrm{D} / \mathrm{M}$ \\
\hline $\begin{array}{l}\text { KEGG BRITE: Glycan } \\
\text { Binding Proteins }\end{array}$ & $\begin{array}{l}\text { Protein classification, links to other KEGG } \\
\text { resources and to external databases }\end{array}$ & $\begin{array}{l}\text { http://www.genome.jp/kegg-bin/get_htext } \\
\text { ?ko04091.keg }\end{array}$ & $\mathrm{D} / \mathrm{M}$ \\
\hline $\begin{array}{l}\text { Lectin Frontier Database } \\
\text { (JCGGDB) }\end{array}$ & Includes glycan array data & $\begin{array}{l}\text { http://riodb.ibase.aist.go.jp/rcmg/glycodb/ } \\
\underline{\text { LectinSearch }}\end{array}$ & $\mathrm{D} / \mathrm{M}$ \\
\hline LECTINES & $\begin{array}{l}\text { Collection of lectin 3D structures from the } \\
\text { PDB }\end{array}$ & http://www.cermav.cnrs.fr/lectines/ & $\mathrm{D} / \mathrm{M}$ \\
\hline $\begin{array}{l}\text { PACDB (JCGGDB Pathogen } \\
\text { Adherence to Carbohydrate } \\
\text { DB) }\end{array}$ & $\begin{array}{l}\text { Pathogen adherence molecule, host } \\
\text { glycan/glycoprotein ligand, bibliography }\end{array}$ & http://jcggdb.jp/search/PACDB.cgi & $\mathrm{D} / \mathrm{M}$ \\
\hline
\end{tabular}

aD/M: Database is further developed and/or maintained; S: Development/maintenance is stopped (or, in the case of CFG resources, will be stopped soon because funding will discontinue).

tion in ECODAB [23] is limited to E. coli enzymes. GlycoGeneDB as part of the JCGGDB portal also holds data on glyco-enzymes, including information on substrate specificity, which is important when the enzymes are to be used to synthesize glycan structures in the lab.

Information on glycan-binding proteins (GBPs) or lectins is stored in various databases such as CFG GBP DB, GlycoEpitopeDB [54], the Glycan Binding Proteins section of KEGG BRITE, Lectin Frontier Database, and GlyAffinity. KEGG BRITE mainly links to other resources within and outside the KEGG portal, providing protein sequences, classifications, and information regarding related diseases. GlycoEpitopeDB provides information on antibodies that recognize specific carbohydrate epitopes and glycoproteins or glycolipids that are known to carry the epitopes.

A frequently used technique to study the epitopes, to which a GBP binds, are glycan arrays [4]. CFG Glycan Binding Proteins DB and Lectin Frontier Database store data of glycan array experiments and thus also provide information on the glycan specificity of GBPs. Glycan array data from these two resources and from other research groups are collected and available via a common interface in GlyAffinity. PACDB (Pathogen Adher- 
ence Carbohydrate Database) lists glycan-binding proteins that are involved in the adherence of pathogens to the host. The data are extracted from the literature and can be accessed by pathogen names or by related diseases.

\section{Integration of carbohydrate databases}

It is obvious that a lot of knowledge on carbohydrates is stored in the databases, but also that this knowledge is widely spread over the resources. In contrast to genomics or proteomics databases, hardly any exchange of data is carried out between glycan databases. However, some attempts have been made to cross-reference corresponding entries or to allow cross-database searches. As already mentioned above, the individual databases of JCGGDB are cross-linked with each other, as well as the different KEGG resources. Links between these two initiatives also exist.

Cross-references have also been established between distinct resources. BCSDB and Glycosciences.DB, for example, allow cross-database searches, in which users can simultaneously query both resources [58]. Furthermore, there are links available between corresponding entries of the CFG Glycan Structure Database and Glycosciences.DB, but these links are not updated any more, i.e., recently added entries are not covered. Despite these first attempts, it is still rather cumbersome to search for information on a specific glycan structure, as most resources have not only developed individual interfaces, to which the user has to adapt, but they also use individual ways to encode the carbohydrate structures. CarbBank, for example, used a two-dimensional notation that is similar to IUPAC extended notation [59]. This notation is relatively easy for the human user to survey, but is difficult to handle computationally. Therefore, most databases have developed more clearly defined notations to store carbohydrate structures, such as the LINUCS notation [60] of Glycosciences.de, the LinearCode ${ }^{\circledR}$ used within the CFG databases, GlycoCT [61] in EUROCarbDB, or KCF [62] in KEGG GLYCAN. The usage of individual notations is one of the main reasons that hamper the integration of carbohydrate databases. Conversion of one notation to another is often difficult because they do not only differ in the way in which the linkages are encoded and the branching is handled, but also in the denotation of residue names. Dictionaries of frequently occurring monosaccharides can be created manually, but unusual residues, as can be found in bacterial or synthetic glycans, are difficult to handle in this way. This issue is tackled by MonosaccharideDB, which provides routines to automatically parse and encode carbohydrate residues in various notations.

GlycomeDB [28-30] aims to overcome the problem of poor integration of carbohydrate databases by collecting carbohy- drate structures and taxonomy data from other databases, namely BCSDB, CarbBank, CFG, EUROCarbDB, GlycoBase (Lille), Glycosciences.DB, and KEGG GLYCAN. Carbohydrate-containing PDB entries are also included by extracting this information from Glycosciences.DB. The glycan structures are translated to a common notation (GlycoCT) by using manually curated dictionaries and MonosaccharideDB routines. Glycans are also stored in GLYDE-II encoding [63,64], which was agreed on as a general carbohydrate data-exchange format [9]. All structures in GlycomeDB can be accessed via a common interface, which allows searches by (sub-)structure, similarity, maximum common substructure, and species. Individual entries mainly provide links to the original database entries in the resources, from which the structures were obtained. This way, GlycomeDB serves as a search engine that allows users to easily navigate through several databases without having to query all resources individually. However, it does not contain further data beyond structural and taxonomic information. Integrating more data offers the possibility of performing systems biology analyses. Such approaches are served by JCGGDB, as already mentioned above, and the newly founded UniCarbKB project [65]. At the time of writing this article, however, UniCarbKB is still in a very early stage.

\section{Statistical analyses of carbohydrate data- bases aid the planning of glycan synthesis}

Information extracted from glycan structure databases can be useful for glycochemists not only to find potential synthesis targets but also to plan efficient synthesis approaches by providing lists of building blocks that are minimally necessary to synthesize a large number of glycan structures stored in the databases. An analysis of mammalian carbohydrate structures present in Glycosciences.DB, for example, revealed that this data set contained 3299 oligosaccharides, which are part of $\mathrm{N}$-glycans, $\mathrm{O}$-glycans or glycolipids from 38 mammalian species. Only ten different monosaccharides were found in this data set [66]. However, different anomeric configurations and some substitutions, such as sulfate groups, were ignored, and no distinction was made between $N$-acetylneuraminic acid (Neu5Ac) and $N$-glycolylneuraminic acid (Neu5Gc). The large number of different oligosaccharides that are formed from this relatively small number of different residues arises from the fact that the monosaccharides can be linked in several ways, which has to be considered when creating a set of building blocks for the chemical synthesis of these glycans. Nevertheless, 25 building blocks are sufficient to synthesize $60 \%$ of the mammalian glycans stored in the database, and with 36 building blocks $75 \%$ of the glycans can be created chemically [66].

The situation is much more complex where bacterial carbohydrates are concerned. The variety of different monosaccharides 
as well as of different disaccharide pairs that are present in bacterial glycomes is significantly larger than in the mammalian glycome, featuring many residues that do not occur in mammals, but also exhibiting differentiation between individual classes of bacteria [1,2]. Due to the complexity of residue notation this structural diversity is a challenge for glycoinformatics, but it also offers many possibilities to synthesize carbohydrates or glycomimetics that target specific pathogen proteins. For example, oligosaccharide motifs that are found in surface carbohydrates of pathogens, but not in host organisms or in symbiotes, can serve as templates in vaccine development [67-70], and glycomimetics that block specific enzymes or lectins can be used for therapeutic purposes [71-77].

The Glycan Pathway Prediction (GPP) tool of the RINGS portal [78] can be used to predict glycans that can be obtained with a given glycan structure and a set of enzymes. If knowledge of gene expression is available, e.g., from gene microarray experiments, KEGG Gene Expression to Chemical Structure (GECS) can be used to predict the $N$-glycan chains that can be created by the expressed glyco-enzymes. Further tools that are available for the analysis and conversion of glycan sequence data are summarized in Table 3. The Glycan Fingerprints approach to calculate the degree of diversity in a set of glycan structures is a useful tool to, e.g., evaluate the glycans that are present on a glycan array [79]. GlycanBuilder [80] and DrawRings are used by some databases to enable graphical input of glycan (sub-)structure queries using icons to describe monosaccharides. Atomic pictograms as frequently used by chemists, however, are not supported by these tools.

\section{D Structure information for targeted drug design}

Knowledge of the 3D structure of the target protein and its ligand is a prerequisite for a targeted design of therapeutic glycomimetics [74]. Protein 3D structures are stored in the Protein Data Bank (PDB, [40]). The PDB offers various options to search for proteins. Finding specific carbohydrate structures within PDB entries, however, can be difficult when using PDB queries only. Instead, glycan databases that provide links to PDB entries such as GlycoconjugateDB or Glycosciences.DB can be used. The LECTINES database lists PDB entries of lectins grouped by lectin families. Unfortunately, carbohydrate moieties in the PDB are of significantly lower quality than the protein parts [26,84-86]. Reasons for this are both the greater complexity of carbohydrates, and the fact that, while numerous validation tools are available for protein structures [87], only a few programs exist to validate carbohydrate 3D structures. The PDB carbohydrate residue check (pdb-care) tool [88] aids researchers with locating errors in carbohydrate 3D structures (3D structure-related tools are summarized in Table 4). Ramachandran-like plots of glycosidic torsions are generated by CARP [89], which compares torsions observed in a given 3D structure with computationally derived conformational maps of GlycoMapsDB [27] or with torsions present in carbohydrates in the PDB provided by glyTorsion [89]. In contrast to protein backbone torsions, unusual glycosidic torsions do not necessarily indicate errors in the 3D structure because the conformation of a carbohydrate ligand in complex with a protein can differ from the preferred conformation in solution $[90,91]$. Nevertheless, CARP plots can help researchers to find potential problems, as well as indicate unusual binding conformations that

Table 3: Tools to input, convert, or analyze glycan structures.

\begin{tabular}{|c|c|c|}
\hline Name, Ref & Comment & URL \\
\hline DrawRings & Visual editor of glycan structures & $\frac{\text { http://rings.t.soka.ac.jp/cgi-bin/tools/DrawRings/dra }}{\text { wrings2.pl }}$ \\
\hline $\begin{array}{l}\text { GECS (Gene Expression to } \\
\text { Chemical Structure) [81] }\end{array}$ & $\begin{array}{l}\text { Prediction of } N \text {-glycan chains from gene } \\
\text { expression data }\end{array}$ & http://www.genome.jp/tools/gecs/ \\
\hline GlycanBuilder [80] & Visual editor of glycan structures & http://www.glycoworkbench.org/wiki/GlycanBuilder \\
\hline Glycan Fingerprints [79] & $\begin{array}{l}\text { Estimation of the degree of diversity in a set } \\
\text { of glycan structures }\end{array}$ & - \\
\hline Glycan Miner [82] & $\begin{array}{l}\text { Detection of motifs or significant subtrees in } \\
\text { a set of glycan structures }\end{array}$ & $\frac{\text { http://rings.t.soka.ac.jp/cgi-bin/tools/GlycanMiner/Mi }}{\underline{\text { ner_index.pl }}}$ \\
\hline $\begin{array}{l}\text { GPP (Glycan Pathway } \\
\text { Predictor) }\end{array}$ & $\begin{array}{l}\text { Computes } N \text {-glycan biosynthesis pathway for } \\
\text { a given glycan structure }\end{array}$ & $\frac{\text { http://rings.t.soka.ac.jp/cgi-bin/tools/GPP/gpp_inde }}{\underline{\text { x.pl }}}$ \\
\hline LiGraph & Builds graphical representations of glycans & http://www.glycosciences.de/tools/LiGraph/ \\
\hline ProfilePSTMM [83] & $\begin{array}{l}\text { Generates glycan profiles from glycan } \\
\text { structure data }\end{array}$ & $\begin{array}{l}\text { http://rings.t.soka.ac.jp/cgi-bin/tools/ProfilePSTMM/ } \\
\text { profile-training_index.pl }\end{array}$ \\
\hline Sumo (Sugar Motif Search) & $\begin{array}{l}\text { Detects frequently occurring motifs in a } \\
\text { glycan structure }\end{array}$ & http://www.glycosciences.de/tools/sumo/ \\
\hline
\end{tabular}


Table 4: Tools for prediction and analysis of carbohydrate/glycoprotein 3D structures

\begin{tabular}{|c|c|c|}
\hline Name, Ref & Comment & URL \\
\hline BALLDock/SLICK $[92,93]$ & Protein-carbohydrate docking & \\
\hline CARP [89] & $\begin{array}{l}\text { Ramachandran plot-like analysis of glycosidic } \\
\text { torsions }\end{array}$ & http://www.glycosciences.de/tools/carp/ \\
\hline CAT & $\begin{array}{l}\text { Conformational analysis tool, for analysis of MD } \\
\text { trajectories }\end{array}$ & http://www.md-simulations.de/CAT/ \\
\hline $\begin{array}{l}\text { GLYCAM Biomolecules } \\
\text { Builder [42] }\end{array}$ & $\begin{array}{l}\text { Generation of glycan models and in silico } \\
\text { glycosylation of proteins, preparation of input files } \\
\text { for AMBER }[94,95]\end{array}$ & http://glycam.ccrc.uga.edu/ccrc/pages/3dspt.html \\
\hline Glycan Reader [96] & $\begin{array}{l}\text { Detection of carbohydrates in PDB files, } \\
\text { preparation of input files for CHARMM [97] }\end{array}$ & http://www.charmm-gui.org/input/glycan \\
\hline glyProt [98] & in silico glycosylation of proteins & http://www.glycosciences.de/modeling/glyprot/ \\
\hline glyTorsion [89] & $\begin{array}{l}\text { Statistics of torsion angles of carbohydrate } \\
\text { structures in the PDB }\end{array}$ & http://www.glycosciences.de/tools/glytorsion/ \\
\hline glyVicinity [89] & $\begin{array}{l}\text { Amino acids in the spatial vicinity of } \\
\text { carbohydrates in the PDB }\end{array}$ & http://www.glycosciences.de/tools/glyvicinity/ \\
\hline pdb2linucs [85] & Detection of carbohydrates in PDB files & http://www.glycosciences.de/tools/pdb2linucs/ \\
\hline pdb-care [88] & Validation of carbohydrate 3D structure files & http://www.glycosciences.de/tools/pdbcare/ \\
\hline Sweet-II [39] & Prediction of carbohydrate 3D structures & http://www.glycosciences.de/modeling/sweet2/ \\
\hline
\end{tabular}

have to be taken into account when planning the synthesis of glycomimetics.

In many cases, however, no carbohydrate ligands are present in PDB entries of glycan-binding proteins. Glycan chains of glycoproteins are also often missing, or only a fraction of a chain is present in the coordinates. In such cases, tools such as Sweet-2 [39] or GLYCAM Biomolecule Builder [42] can be used to create models of carbohydrate chains. The latter program can also perform in silico glycosylation by adding the glycan chains to a protein 3D structure, and provides input files for the AMBER [94,95] modeling programs using the GLYCAM force field [99]. Glycan 3D structures calculated by Sweet-2 can be linked to a protein with glyProt [98]. When using these tools to create conformational models of carbohydrates or glycoproteins, one should always keep in mind that these are models and do not represent the one and only "correct" conformation. As glycans are rather flexible molecules, they adopt several conformations with different populations. The conformational space of a glycan can be analyzed by molecular dynamics (MD) simulations (see in the following) [100]. For this purpose the models generated by the GLYCAM Biomolecules Builder are convenient, as this tool already provides the input files for AMBER simulations. The list of residues that are available, however, is more limited than in Sweet-2. Sulfated residues, which frequently occur in glycosaminoglycans [101], for example, are only supported by Sweet-2 at the moment. GlycanReader [96] as part of the CHARMM-GUI [102] creates CHARMM [97] input files from
PDB files that contain carbohydrates. Various tools to predict the occupancy state of potential glycosylation sites from protein sequence data are available as well (Table 5).

If a protein-carbohydrate complex is to be modeled, generally available docking tools such as AutoDock [113] can be used to identify the binding position. These tools, however, often do not sufficiently consider the peculiarities of protein-carbohydrate complexes, such as $\mathrm{CH}-\pi$ interactions [13]. Therefore, BALLDock/SLICK has been developed specifically for protein-carbohydrate docking [92,93]. One of the major problems of docking algorithms in general is the identification of the correct conformation among the potential binding modes [100]. Therefore, computational docking approaches are frequently combined with wet-lab experiments, such as saturation transfer difference NMR (STD NMR) or transferred nuclear Overhauser effect (trNOE) spectroscopy [75,114-116], to reliably assign the correct conformation of the ligand on the protein surface. Such combinations of experimental and theoretical approaches are also useful to determine the conformations of natural carbohydrates or their synthetic glycan mimetics [117119]. Results can be improved by combinations of different modeling approaches, such as docking and MD simulations [101]. To run reliable MD simulations of carbohydrate 3D structures, force fields are necessary that contain parameters for carbohydrates. In the case of glycoproteins, protein-carbohydrate complexes, or glycolipids, the force fields have to cover all types of molecules involved [100,120]. The force fields need to be extensible if not only standard monosaccharides, but also 
Table 5: Prediction and analysis of glycosylation sites.

\begin{tabular}{|c|c|c|}
\hline Name, Ref & Comment & URL \\
\hline big-PI [103] & GPI anchor modification site prediction & http://mendel.imp.ac.at/sat/gpi/gpi_server.html \\
\hline CBS prediction servers & $\begin{array}{l}\text { Collection of various prediction tools, including } \\
\text { NetNGlyc, NetOGlyc [104], NetCGlyc [105], } \\
\text { NetGlycate [106], DictyOGlyc [107], YingOYang } \\
\text { [108] }\end{array}$ & http://cbs.dtu.dk/services/ \\
\hline CKSAAP_OGlySite [109] & Prediction of mucin-type O-glycosylation sites & $\begin{array}{l}\text { http://bioinformatics.cau.edu.cn/zzd_lab/CKS } \\
\text { AAP_OGlySite/ }\end{array}$ \\
\hline EnsembleGly [110] & $\begin{array}{l}\text { Prediction of } \mathrm{O}-, \mathrm{N}-\text {, and } \mathrm{C} \text {-linked glycosylation } \\
\text { sites }\end{array}$ & http://turing.cs.iastate.edu/EnsembleGly/ \\
\hline glySeq [89] & $\begin{array}{l}\text { Statistical analysis of amino acids around } \\
\text { glycosylation sites }\end{array}$ & http://www.glycosciences.de/tools/glyseq/ \\
\hline GPI-SOM [111] & Identification of GPI-anchor signals & http://gpi.unibe.ch \\
\hline GPP [112] & Prediction of $\mathrm{N}$ - and O-glycosylation sites & http://comp.chem.nottingham.ac.uk/glyco/ \\
\hline
\end{tabular}

derivatized residues are included in a simulation, which is especially important during the design of glycomimetics [121]. Parameters that affect the simulations of carbohydrates include the treatment of atom charges [122], and solvent model (several models for water are available) [100]. The question of whether to include extra terms for (exo) anomeric effects has also been discussed for a long time [13].

With increasing computational power, MD simulations of larger molecules become feasible; and timescales of simulations increase. One major bottleneck for the scientific use of MD simulations that involve carbohydrates is, therefore, the availability of tools to analyze these simulation trajectories [13]. MD software packages contain analysis tools [94,97,123], but these are tailored for analyzing simulations of proteins. Therefore, tools such as CAT (Conformational Analysis Tools) that serve the needs of glycoscientists are specifically developed [13].

\section{Glycoinformatics in carbohydrate structure analysis}

After synthesis of carbohydrate chains an assessment of the quality of the produced material is necessary to exclude wrong structures among the products. Errors in structures that are meant for use in experiments such as glycan arrays may yield incorrect results and thereby lead to mistaken conclusions. Incorrect products that are used as therapeutics can have severe results. Impurities in heparin, a widely used carbohydrate pharmaceutical, for example, can even be fatal [124-126]. The major methods for quality control comprise MS, NMR, and HPLC, all of which produce large amounts of data that have to be evaluated. Companies that develop the analytical equipment that is necessary for these techniques usually do not focus on the detection or analysis of carbohydrates and their software does not suit the needs of glycoscientists [12]. Nevertheless, various community-developed tools exist that facilitate the carbohydrate-specific interpretation of these data (Table 6).

Among the three techniques, the largest choice of tools is available for mass spectrometry. These programs commonly first try and assign residue compositions to measured mass peaks, but use different approaches to determine glycan sequences from compositional data. Some tools such as Cartoonist [127,128] and GlycoMod [132] apply constraints that are created from the knowledge of biosynthetic pathways, thus they are tailored to the analysis of biological samples rather than of chemically synthesized glycans, which do not match the biosynthetic pathways. In contrast, the mass fingerprinting approach as implemented in GlycosidIQ [137], GlypPep ID [134], or GlycoSearch-MS [136] works similarly to algorithms that are frequently used in peptide or protein identification by tools such as Mascot: Mass peaks that are observed in a spectrum are compared to theoretically derived fragment masses that are computed from glycan structures stored in a carbohydrate database. This approach, however, is limited by the content of the database that provides the templates for in silico fragmentation, which means that structures that have not been observed before or that are missing from the database will not be identified this way. This problem also applies to programs that use experimental $\mathrm{MS}^{\mathrm{n}}$ data of oligosaccharide standards to assign $\mathrm{MS}^{\mathrm{n}}$ fragments of larger glycans, such as GLYCH [129] or $\mathrm{MS}^{\mathrm{n}}$ FragLib [140]. In contrast, programs such as STAT [142], StrOligo [143], or OSCAR [141] also allow de novo determination of structures because they interpret $\mathrm{MS}^{\mathrm{n}}$ data by determining the possible compositions of parent ions according to their masses; subsequently, the masses of possible connected branching topologies are computed to match the experimentally determined data [149]. GlyQuest [139] and GlycoMiner [131] are designed for high-throughput analysis of glycopeptides that carry $N$-glycan chains. Glyco-Peakfinder [133] and 
Table 6: Tools to support experimental analysis of glycans.

\begin{tabular}{|c|c|c|}
\hline Name, Ref & Comment & URL \\
\hline \multicolumn{3}{|l|}{ Mass spectrometry } \\
\hline Cartoonist $[127,128]$ & Template based glycan sequencing & - \\
\hline GlycanMass & $\begin{array}{l}\text { Calculates the mass of an oligosaccharide } \\
\text { structure }\end{array}$ & http://web.expasy.org/glycanmass/ \\
\hline GLYCH [129] & De novo sequencing of glycans & - \\
\hline GlycoFragment [130] & $\begin{array}{l}\text { Calculation of theoretical mass fragments of } \\
\text { glycans }\end{array}$ & $\begin{array}{l}\text { http://www.glycosciences.de/tools/GlycoFragm } \\
\text { ents/ }\end{array}$ \\
\hline GlycoMiner [131] & Glycopeptide (N-glycan) composition analysis & $\overline{\mathrm{http}: / / w w w . c h e m r e s . h u / m s / g l y c o m i n e r /}$ \\
\hline GlycoMod [132] & $\begin{array}{l}\text { Prediction of oligosaccharide structures of } \\
\text { glycoproteins from mass peaks }\end{array}$ & http://www.expasy.org/tools/glycomod/ \\
\hline Glyco-Peakfinder [133] & $\begin{array}{l}\text { Composition annotation of glycans in MS } \\
\text { spectra }\end{array}$ & http://www.glyco-peakfinder.org \\
\hline GlycoPep ID [134] & Glycan mass fingerprinting & http://hexose.chem.ku.edu/predictiontable.php \\
\hline GlycoPeptideSearch [135] & $\begin{array}{l}\text { Glycan mass fingerprinting (MS/MS) of } \\
N \text {-glycopeptides using GlycomeDB glycans }\end{array}$ & $\begin{array}{l}\text { http://edwardslab.bmcb.georgetown.edu/softwa } \\
\text { re/GlycoPeptideSearch.html }\end{array}$ \\
\hline Glyco-Search-MS [136] & $\begin{array}{l}\text { Glycan mass fingerprinting using } \\
\text { Glyocsciences.DB glycans }\end{array}$ & $\begin{array}{l}\text { http://www.glycosciences.de/database/start.php } \\
\text { ?action=form_ms_search }\end{array}$ \\
\hline GlycosidIQ [137] & $\begin{array}{l}\text { Glycan mass fingerprinting using GlycoSuiteDB } \\
\text { glycans }\end{array}$ & - \\
\hline GlycoWorkbench [138] & Assists interpretation of MS spectra & http://www.glycoworkbench.org \\
\hline GlyQuest [139] & Glycopeptide ( $N$-glycan) analysis & - \\
\hline MS ${ }^{n}$ FragLib [140] & $\begin{array}{l}\text { Glycan characterization based on an } \mathrm{MS}^{n} \\
\text { fragment spectral library }\end{array}$ & - \\
\hline OSCAR [141] & De novo sequencing of glycans & - \\
\hline Peptoonist [127] & $\begin{array}{l}\text { Identification of } N \text {-glycopeptides from a series } \\
\text { of mass spectra (MS and MS/MS) }\end{array}$ & - \\
\hline $\begin{array}{l}\text { PMAA (Partially Methylated } \\
\text { Alditol Acetate) }\end{array}$ & $\begin{array}{l}\text { GC-MS fragmentation of permethylated } \\
\text { monosaccharides }\end{array}$ & $\frac{\text { http://www.ccrc.uga.edu/specdb/ms/pmaa/pfra }}{\text { me.html }}$ \\
\hline STAT [142] & De novo sequencing of glycans & - \\
\hline StrOligo [143] & De novo sequencing of glycans & - \\
\hline
\end{tabular}

\section{NMR}

\begin{tabular}{|c|c|c|}
\hline CASPER $[144,145]$ & $\begin{array}{l}\text { Simulation of NMR spectra, glycan sequence } \\
\text { determination from chemical shifts }\end{array}$ & http://www.casper.organ.su.se/casper/ \\
\hline CCPN [146] & NMR annotation software & http://www.ccpn.ac.uk \\
\hline GlyNest [147] & Estimation of NMR chemical shifts & $\begin{array}{l}\text { http://www.glycosciences.de/sweetdb/start.php } \\
\text { ?action=form shift estimation }\end{array}$ \\
\hline ProspectND & NMR data processing and inspection & http://prospectnd.sourceforge.net/ \\
\hline \multicolumn{3}{|l|}{ HPLC } \\
\hline AutoGU [25] & Interpretation of HPLC data & - \\
\hline GALAXY [148] & Visualization of HPLC 2D maps & http://www.glycoanalysis.info/ENG/index.html \\
\hline
\end{tabular}

GlycoWorkbench [138] cover the complete workflow from recorded experimental data to a fully assigned spectrum or to glycan structure determination [150]. GlycoWorkbench also facilitates upload of primary data into EUROCarbDB [24]. Furthermore, it enables user-defined residues, which is important when chemically synthesized glycans are to be analyzed. Such glycans may contain highly modified monosaccharides, protecting groups, linkers, or other kinds of nonstandard residues, which are neither included in the standard residue sets nor present in the databases used by mass-fingerprinting approaches.

Significantly fewer tools are available to aid the interpretation of HPLC or NMR spectra of carbohydrates. AutoGU [25] and GALAXY [148] assist users to interpret HPLC profiles or to visualize HPLC 2D maps, respectively. ProspectND is designed 
for the signal processing of multidimensional NMR spectra. CCPN (Collaborative Computing Project for the NMR community) helps users to assign NMR spectra [146,151]. Originally designed for proteins or peptides, CCPN by now also supports carbohydrates. Other tools such as CASPER [144,145,152-154] or GlyNest [147] can be used to predict 1D NMR spectra of carbohydrates and to determine glycan sequences from chemical shifts.

\section{Conclusion}

Due to the challenges that carbohydrates pose, not only with respect to their analysis or synthesis but also in the handling of them computationally, glycoinformatics has been lagging behind other areas of bioinformatics for a long time [6], but has made good progress over the past decade and is catching up with bioinformatics for genomics or proteomics. Despite this relatively quick growth and some promising approaches to cross-reference and standardize the data $[9,10,28,58,65]$, there is still an urgent need for better integration of the various resources [13], many of which can still be regarded as disconnected islands. Furthermore, funding for the maintenance of existing databases is required to keep useful resources up-todate, rather than only funding new projects. The open-source idea can also help to partly overcome this dilemma. If the data and source codes that have been developed in a project are accessible to other researchers, they can be used in new projects to actually improve the existing status, rather than the wheel having to be reinvented every time by starting from scratch and redeveloping basic concepts and sources.

\section{References}

1. Herget, S.; Toukach, P. V.; Ranzinger, R.; Hull, W. E.; Knirel, Y. A.; von der Lieth, C.-W. BMC Struct. Biol. 2008, 8, No. 35. doi:10.1186/1472-6807-8-35

2. Adibekian, A.; Stallforth, P.; Hecht, M.-L.; Werz, D. B.; Gagneux, P.; Seeberger, P. H. Chem. Sci. 2011, 2, 337-344. doi:10.1039/c0sc00322k

3. Varki, A.; Cummings, R. D.; Esko, J. D.; Freeze, H. H.; Stanley, P.; Bertozzi, C. R.; Hart, G. W.; Etzler, M. E., Eds. Essentials of Glycobiology, 2nd ed.; Cold Spring Harbor Laboratory Press: Plainview, NY, 2009.

4. Rillahan, C. D.; Paulson, J. C. Annu. Rev. Biochem. 2011, 80, 797-823. doi:10.1146/annurev-biochem-061809-152236

5. Bernardes, G. J. L.; Castagner, B.; Seeberger, P. H. ACS Chem. Biol. 2009, 4, 703-713. doi:10.1021/cb900014n

6. von der Lieth, C.-W.; Bohne-Lang, A.; Lohmann, K. K.; Frank, M. Briefings Bioinf. 2004, 5, 164-178. doi:10.1093/bib/5.2.164

7. von der Lieth, C.-W.; Lütteke, T.; Frank, M. Biochim. Biophys. Acta, Gen. Subj. 2006, 1760, 568-577. doi:10.1016/j.bbagen.2005.12.004

8. von der Lieth, C.-W. Databases and Informatics for Glycobiology and Glycomics. In Comprehensive Glycoscience; Kamerling, J. P., Ed.; Elsevier: Oxford, 2007; Vol. 2, pp 329-346.
9. Packer, N. H.; von der Lieth, C.-W.; Aoki-Kinoshita, K. F.; Lebrilla, C. B.; Paulson, J. C.; Raman, R.; Rudd, P.; Sasisekharan, R.; Taniguchi, N.; York, W. S. Proteomics 2008, 8, 8-20. doi:10.1002/pmic.200700917

10. Katayama, T.; Arakawa, K.; Nakao, M.; Ono, K.; Aoki-Kinoshita, K. F.; Yamamoto, Y.; Yamaguchi, A.; Kawashima, S.; Chun, H.-W.; Aerts, J.; Aranda, B.; Barboza, L. H.; Bonnal, R. J. P.; Bruskiewich, R.; Bryne, J. C.; Fernández, J. M.; Funahashi, A.; Gordon, P. M. K.; Goto, N.; Groscurth, A.; Gutteridge, A.; Holland, R.; Kano, Y.; Kawas, E. A.; Kerhornou, A.; Kibukawa, E.; Kinjo, A. R.; Kuhn, M.; Lapp, H.; Lehvaslaiho, H.; Nakamura, H.; Nakamura, Y.; Nishizawa, T.; Nobata, C.; Noguchi, T.; Oinn, T. M.; Okamoto, S.; Owen, S.; Pafilis, E.; Pocock, M.; Prins, P.; Ranzinger, R.; Reisinger, F.; Salwinski, L.; Schreiber, M.; Senger, M.; Shigemoto, Y.; Standley, D. M.; Sugawara, H.; Tashiro, T.; Trelles, O.; Vos, R. A.; Wilkinson, M. D.; York, W.; Zmasek, C. M.; Asai, K.; Takagi, T. J. Biomed. Semantics 2010, 1, No. 8. doi:10.1186/2041-1480-1-8

11. MIRAGE Consortium. http://glycomics.ccrc.uga.edu/MIRAGE/index.php/Main_Page (accessed May 9, 2012).

12. Ranzinger, R.; Maass, K.; Lütteke, T. Bioinformatics Databases and Applications Available for Glycobiology and Glycomics. In Functional and Structural Proteomics of Glycoproteins; Owens, R.; Nettleship, J., Eds.; Springer: New York, 2011; pp 59-90.

13. Frank, M.; Schloissnig, S. Cell. Mol. Life Sci. 2010, 67, 2749-2772. doi:10.1007/s00018-010-0352-4

14. Lütteke, T. ChemBioChem 2008, 9, 2155-2160. doi:10.1002/cbic.200800338

15. Aoki-Kinoshita, K. F.; Kanehisa, M. Curr. Opin. Mol. Ther. 2006, 8, 514-520.

16. Peréz, S.; Mulloy, B. Curr. Opin. Struct. Biol. 2005, 15, 517-524. doi:10.1016/j.sbi.2005.08.005

17. Berteau, O.; Stenutz, R. Carbohydr. Res. 2004, 339, 929-936. doi:10.1016/j.carres.2003.11.008

18. Toukach, P. V. J. Chem. Inf. Model. 2011, 51, 159-170. doi:10.1021/ci100150d

19. Doubet, S.; Bock, K.; Smith, D.; Darvill, A.; Albersheim, P. Trends Biochem. Sci. 1989, 14, 475-477. doi:10.1016/0968-0004(89)90175-8

20. Doubet, S.; Albersheim, P. Glycobiology 1992, 2, 505. doi:10.1093/glycob/2.6.505

21. Raman, R.; Venkataraman, M.; Ramakrishnan, S.; Lang, W.; Raguram, S.; Sasisekharan, R. Glycobiology 2006, 16, 82R-90R. doi:10.1093/glycob/cwj080

22. Stenutz, R.; Weintraub, A.; Widmalm, G. FEMS Microbiol. Rev. 2006, 30, 382-403. doi:10.1111/j.1574-6976.2006.00016.x

23. Lundborg, M.; Modhukur, V.; Widmalm, G. Glycobiology 2010, 20, 366-368. doi:10.1093/glycob/cwp185

24. von der Lieth, C.-W.; Freire, A. A.; Blank, D.; Campbell, M. P.; Ceroni, A.; Damerell, D. R.; Dell, A.; Dwek, R. A.; Ernst, B.; Fogh, R.; Frank, M.; Geyer, H.; Geyer, R.; Harrison, M. J.; Henrick, K.; Herget, S.; Hull, W. E.; lonides, J.; Joshi, H. J.; Kamerling, J. P.; Leeflang, B. R.; Lütteke, T.; Lundborg, M.; Maass, K.; Merry, A.; Ranzinger, R.; Rosen, J.; Royle, L.; Rudd, P. M.; Schloissnig, S.; Stenutz, R.; Vranken, W. F.; Widmalm, G.; Haslam, S. M. Glycobiology 2011, 21, 493-502. doi:10.1093/glycob/cwq188

25. Campbell, M. P.; Royle, L.; Radcliffe, C. M.; Dwek, R. A.; Rudd, P. M. Bioinformatics 2008, 24, 1214-1216. doi:10.1093/bioinformatics/btn090 
26. Nakahara, T.; Hashimoto, R.; Nakagawa, H.; Monde, K.; Miura, N.; Nishimura, S.-I. Nucleic Acids Res. 2008, 36 (Suppl. 1), D368-D371. doi:10.1093/nar/gkm833

27. Frank, M.; Lütteke, T.; von der Lieth, C.-W. Nucleic Acids Res. 2007, 35 (Suppl. 1), 287-290. doi:10.1093/nar/gkl907

28. Ranzinger, R.; Herget, S.; Wetter, T.; von der Lieth, C.-W. BMC Bioinf. 2008, 9, No. 384. doi:10.1186/1471-2105-9-384

29. Ranzinger, R.; Frank, M.; von der Lieth, C.-W.; Herget, S. Glycobiology 2009, 19, 1563-1567. doi:10.1093/glycob/cwp137

30. Ranzinger, R.; Herget, S.; von der Lieth, C.-W.; Frank, M. Nucleic Acids Res. 2011, 39 (Suppl. 1), D373-D376. doi:10.1093/nar/gkq1014

31. Lütteke, T.; Bohne-Lang, A.; Loss, A.; Goetz, T.; Frank, M.; von der Lieth, C.-W. Glycobiology 2006, 16, 71R-81R. doi:10.1093/glycob/cwj049

32. Cooper, C. A.; Harrison, M. J.; Wilkins, M. R.; Packer, N. H. Nucleic Acids Res. 2001, 29, 332-335. doi:10.1093/nar/29.1.332

33. Cooper, C. A.; Joshi, H. J.; Harrison, M. J.; Wilkins, M. R.; Packer, N. H. Nucleic Acids Res. 2003, 31, 511-513. doi:10.1093/nar/gkg099

34. Taniguchi, N. IUBMB Life 2006, 58, 269-272. doi:10.1080/15216540600756020

35. Hashimoto, K.; Goto, S.; Kawano, S.; Aoki-Kinoshita, K. F.; Ueda, N.; Hamajima, M.; Kawasaki, T.; Kanehisa, M. Glycobiology 2006, 16, 63R-70R. doi:10.1093/glycob/cwj010

36. van Kuik, J. A.; Hard, K.; Vliegenthart, J. F. G. Carbohydr. Res. 1992, 235, 53-68. doi:10.1016/0008-6215(92)80078-F

37. Hayes, C. A.; Karlsson, N. G.; Struwe, W. B.; Lisacek, F.; Rudd, P. M. Packer, N. H.; Campbell, M. P. Bioinformatics 2011, 27, 1343-1344. doi:10.1093/bioinformatics/btr137

38. Loß, A.; Bunsmann, P.; Bohne, A.; Loß, A.; Schwarzer, E.; Lang, E.; von der Lieth, C.-W. Nucleic Acids Res. 2002, 30, 405-408. doi:10.1093/nar/30.1.405

39. Bohne, A.; Lang, E.; von der Lieth, C.-W. Bioinformatics 1999, 15, 767-768. doi:10.1093/bioinformatics/15.9.767

40. Berman, H. M.; Westbrook, J.; Feng, Z.; Gilliland, G.; Bhat, T. N.; Weissig, H.; Shindyalov, I. N.; Bourne, P. E. Nucleic Acids Res. 2000, 28, 235-242. doi:10.1093/nar/28.1.235

41. Lütteke, T.; von der Lieth, C.-W. Biocatal. Biotransform. 2006, 24 , 147-155. doi:10.1080/10242420600598269

42. Woods Group (2005-2012) GLYCAM Web, Complex Carbohydrate Research Center, University of Georgia, Athens, GA (http://www.glycam.com).

43. Degtyarenko, K.; Hastings, J.; de Matos, P.; Ennis, M. Curr. Protoc. Bioinformatics 2009, Chapter, 14, Unit 14-19.

44. de Matos, P.; Adams, N.; Hastings, J.; Moreno, P.; Steinbeck, C. Methods Mol. Biol. 2012, 803, 273-296. doi:10.1007/978-1-61779-364-6_19

45. Wang, Y.; Xiao, J.; Suzek, T. O.; Zhang, J.; Wang, J.; Bryant, S. H. Nucleic Acids Res. 2009, 37 (Suppl. 2), W623-633. doi:10.1093/nar/gkp456

46. Homann, A.; Seibel, J. Appl. Microbiol. Biotechnol. 2009, 83, 209-216. doi:10.1007/s00253-009-1989-5

47. Huang, W.; Li, C.; Li, B.; Umekawa, M.; Yamamoto, K.; Zhang, X.; Wang, L.-X. J. Am. Chem. Soc. 2009, 131, 2214-2223. doi:10.1021/ja8074677

48. Schmidt, D.; Thiem, J. Beilstein J. Org. Chem. 2010, 6, No. 18. doi:10.3762/bjoc.6.18

49. Palcic, M. M. Curr. Opin. Chem. Biol. 2011, 15, 226-233. doi:10.1016/j.cbpa.2010.11.022
50. Apweiler, R.; Martin, M. J.; O'Donovan, C.; Magrane, M.; Alam-Faruque, Y.; Antunes, R.; Barrell, D.; Bely, B.; Bingley, M.; Binns, D.; Bower, L.; Browne, P.; Chan, W. M.; Dimmer, E.; Eberhardt, R.; Fedotov, A.; Foulger, R.; Garavelli, J.; Huntley, R.; Jacobsen, J.; Kleen, M.; Laiho, K.; Leinonen, R.; Legge, D.; Lin, Q.; Liu, W.; Luo, J.; Orchard, S.; Patient, S.; Poggioli, D.; Pruess, M.; Corbett, M.; di Martino, G.; Donnelly, M.; van Rensburg, P.; Bairoch, A.; Bougueleret, L.; Xenarios, I.; Altairac, S.; Auchincloss, A.; Argoud-Puy, G.; Axelsen, K.; Baratin, D.; Blatter, M.-C.; Boeckmann, B.; Bolleman, J.; Bollondi, L.; Boutet, E.; Quintaje, S. B.; Breuza, L.; Bridge, A.; deCastro, E.; Ciapina, L.; Coral, D.; Coudert, E.; Cusin, I.; Delbard, G.; Doche, M.; Dornevil, D.; Roggli, P. D.; Duvaud, S.; Estreicher, A.; Famiglietti, L.; Feuermann, M.; Gehant, S.; Farriol-Mathis, N.; Ferro, S.; Gasteiger, E.; Gateau, A.; Gerritsen, V.; Gos, A.; Gruaz-Gumowski, N.; Hinz, U.; Hulo, C.; Hulo, N.; James, J.; Jimenez, S.; Jungo, F.; Kappler, T.; Keller, G.; Lachaize, C.; Lane-Guermonprez, L.; Langendijk-Genevaux, P.; Lara, V.; Lemercier, P.; Lieberherr, D.; de Oliveira Lima, T.; Mangold, V.; Martin, X.; Masson, P.; Moinat, M.; Morgat, A.; Mottaz, A.; Paesano, S.; Pedruzzi, I.; Pilbout, S.; Pillet, V.; Poux, S.; Pozzato, M.; Redaschi, N.; Rivoire, C.; Roechert, B.; Schneider, M.; Sigrist, C.; Sonesson, K.; Staehli, S.; Stanley, E.; Stutz, A.; Sundaram, S.; Tognolli, M.; Verbregue, L.; Veuthey, A.-L.; Yip, L.; Zuletta, L.; Wu, C.; Arighi, C.; Arminski, L.; Barker, W.; Chen, C.; Chen, Y.; Hu, Z.-Z.; Huang, H.; Mazumder, R.; McGarvey, P.; Natale, D. A.; Nchoutmboube, J.; Petrova, N.; Subramanian, N.; Suzek, B. E.; Ugochukwu, U.; Vasudevan, S.; Vinayaka, C. R.; Yeh, L. S.; Zhang, J. Nucleic Acids Res. 2010, 38 (Suppl. 1), D142-D148. doi:10.1093/nar/gkp846

51. Chang, A.; Scheer, M.; Grote, A.; Schomburg, I.; Schomburg, D. Nucleic Acids Res. 2009, 37 (Suppl. 1), D588-D592. doi:10.1093/nar/gkn820

52. Cantarel, B. L.; Coutinho, P. M.; Rancurel, C.; Bernard, T.; Lombard, V.; Henrissat, B. Nucleic Acids Res. 2009, 37 (Suppl. 1), D233-D238. doi:10.1093/nar/gkn663

53. Eisenhaber, B.; Maurer-Stroh, S.; Novatchkova, M.; Schneider, G.; Eisenhaber, F. Bioessays 2003, 25, 367-385. doi:10.1002/bies.10254

54. Kawasaki, T.; Nakao, H.; Takahashi, E.; Tominaga, T. Trends Glycosci. Glycotechnol. 2006, 18, 267-272. doi:10.4052/tigg.18.267

55. Altschul, S. F.; Gish, W.; Miller, W.; Myers, E. W.; Lipman, D. J. J. Mol. Biol. 1990, 215, 403-410. doi:10.1016/S0022-2836(05)80360-2

56. Eddy, S. R. Bioinformatics 1998, 14, 755-763. doi:10.1093/bioinformatics/14.9.755

57. Davies, G. J.; Gloster, T. M.; Henrissat, B. Curr. Opin. Struct. Biol. 2005, 15, 637-645. doi:10.1016/j.sbi.2005.10.008

58. Toukach, P.; Joshi, H. J.; Ranzinger, R.; Knirel, Y.; von der Lieth, C.-W. Nucleic Acids Res. 2007, 35 (Suppl. 1), D280-D286. doi:10.1093/nar/gkl883

59. McNaught, A. D. Adv. Carbohydr. Chem. Biochem. 1997, 52, 43-177. doi:10.1016/S0065-2318(08)60089-X

60. Bohne-Lang, A.; Lang, E.; Förster, T.; von der Lieth, C.-W. Carbohydr. Res. 2001, 336, 1-11. doi:10.1016/S0008-6215(01)00230-0

61. Herget, S.; Ranzinger, R.; Maass, K.; von der Lieth, C.-W. Carbohydr. Res. 2008, 343, 2162-2171. doi:10.1016/j.carres.2008.03.011 
62. Aoki, K. F.; Yamaguchi, A.; Ueda, N.; Akutsu, T.; Mamitsuka, H.; Goto, S.; Kanehisa, M. Nucleic Acids Res. 2004, 32 (Suppl. 2), W267-W272. doi:10.1093/nar/gkh473

63. Sahoo, S. S.; Thomas, C.; Sheth, A.; Henson, C.; York, W. S. Carbohydr. Res. 2005, 340, 2802-2807. doi:10.1016/j.carres.2005.09.019

64. York, W. S.; Kochut, K. J.; Miller, J. A.; Sahoo, S.; Thomas, C.; Henson, C. GLYDE-II - GLYcan structural Data Exchange using Connection Tables. http://glycomics.ccrc.uga.edu/GLYDE-II/GLYDE-description_v0.7.pdf.

65. Campbell, M. P.; Hayes, C. A.; Struwe, W. B.; Wilkins, M. R.; Aoki-Kinoshita, K. F.; Harvey, D. J.; Rudd, P. M.; Kolarich, D.; Lisacek, F.; Karlsson, N. G.; Packer, N. H. Proteomics 2011, 11, 4117-4121. doi:10.1002/pmic.201100302

66. Werz, D. B.; Ranzinger, R.; Herget, S.; Adibekian, A.; von der Lieth, C.-W.; Seeberger, P. H. ACS Chem. Biol. 2007, 2, 685-691. doi:10.1021/cb700178s

67. Snippe, H.; van Dam, J. E.; van Houte, A. J.; Willers, J. M.; Kamerling, J. P.; Vliegenthart, J. F. Infect. Immun. 1983, 42, 842-844.

68. Vliegenthart, J. F. G. FEBS Lett. 2006, 580, 2945-2950. doi:10.1016/j.febslet.2006.03.053

69. Astronomo, R. D.; Burton, D. R. Nat. Rev. Drug Discovery 2010, 9 , 308-324. doi:10.1038/nrd3012

70. Avci, F. Y.; Li, X.; Tsuji, M.; Kasper, D. L. Nat. Med. 2011, 17, 1602-1609. doi:10.1038/nm.2535

71. Wilson, J. C.; von Itzstein, M. Curr. Drug Targets 2003, 4, 389-408. doi:10.2174/1389450033491019

72. Haselhorst, T.; Wilson, J. C.; Thomson, R. J.; McAtamney, S.; Menting, J. G.; Coppel, R. L.; von Itzstein, M. Proteins 2004, 56, 346-353. doi:10.1002/prot.20143

73. Russell, R. J.; Haire, L. F.; Stevens, D. J.; Collins, P. J.; Lin, Y. P.; Blackburn, G. M.; Hay, A. J.; Gamblin, S. J.; Skehel, J. J. Nature 2006, 443, 45-49. doi:10.1038/nature05114

74. von Itzstein, M. Nat. Rev. Drug Discovery 2007, 6, 967-974. doi:10.1038/nrd2400

75. Reina, J. J.; Díaz, I.; Nieto, P. M.; Campillo, N. E.; Páez, J. A.; Tabarani, G.; Fieschi, F.; Rojo, J. Org. Biomol. Chem. 2008, 6, 2743-2754. doi:10.1039/b802144a

76. Bhunia, A.; Vivekanandan, S.; Eckert, T.; Burg-Roderfeld, M.; Wechselberger, R.; Romanuka, J.; Bächle, D.; Kornilov, A. V.; von der Lieth, C.-W.; Jiménez-Barbero, J.; Nifantiev, N. E.; Schachner, M.; Sewald, N.; Lütteke, T.; Gabius, H. J.; Siebert, H.-C. J. Am. Chem. Soc. 2010, 132, 96-105. doi:10.1021/ja904334s

77. Schierholt, A.; Hartmann, M.; Lindhorst, T. K. Carbohydr. Res. 2011, 346, 1519-1526. doi:10.1016/j.carres.2011.04.023

78. Akune, Y.; Hosoda, M.; Kaiya, S.; Shinmachi, D.; Aoki-Kinoshita, K. F. OMICS 2010, 14, 475-486. doi:10.1089/omi.2009.0129

79. Rademacher, C.; Paulson, J. C. ACS Chem. Biol. 2012, 7, 829-834. doi:10.1021/cb300003z

80. Ceroni, A.; Dell, A.; Haslam, S. M. Source Code Biol. Med. 2007, 2, No. 3. doi:10.1186/1751-0473-2-3

81. Kawano, S.; Hashimoto, K.; Miyama, T.; Goto, S.; Kanehisa, M. Bioinformatics 2005, 21, 3976-3982. doi:10.1093/bioinformatics/bti666

82. Hashimoto, K.; Takigawa, I.; Shiga, M.; Kanehisa, M.; Mamitsuka, H. Bioinformatics 2008, 24, i167-i173. doi:10.1093/bioinformatics/btn293

83. Aoki-Kinoshita, K. F.; Ueda, N.; Mamitsuka, H.; Kanehisa, M. Bioinformatics 2006, 22, e25-e34. doi:10.1093/bioinformatics/btl244

84. Crispin, M.; Stuart, D. I.; Jones, E. Y. Nat. Struct. Mol. Biol. 2007, 14, 354. doi:10.1038/nsmb0507-354a
85. Lütteke, T.; Frank, M.; von der Lieth, C.-W. Carbohydr. Res. 2004, 339, 1015-1020. doi:10.1016/j.carres.2003.09.038

86. Lütteke, T. Acta Crystallogr., Sect. D: Biol. Crystallogr. 2009, 65, 156-168. doi:10.1107/S0907444909001905

87. Read, R. J.; Adams, P. D.; Arendall, W. B.; Brunger, A. T.; Emsley, P.; Joosten, R. P.; Kleywegt, G. J.; Krissinel, E. B.; Lütteke, T.; Otwinowski, Z.; Perrakis, A.; Richardson, J. S.; Sheffler, W. H.; Smith, J. L.; Tickle, I. J.; Vriend, G.; Zwart, P. H. Structure 2011, 19, 1395-1412. doi:10.1016/j.str.2011.08.006

88. Lütteke, T.; von der Lieth, C.-W. BMC Bioinf. 2004, 5, No. 69. doi:10.1186/1471-2105-5-69

89. Lütteke, T.; Frank, M.; von der Lieth, C.-W. Nucleic Acids Res. 2005, 33 (Suppl. 1), D242-D246. doi:10.1093/nar/gki013

90. Raman, R.; Venkataraman, G.; Ernst, S.; Sasisekharan, V.; Sasisekharan, R. Proc. Natl. Acad. Sci. U. S. A. 2003, 100, 2357-2362. doi:10.1073/pnas.0437842100

91. Bhunia, A.; Schwardt, O.; Gäthje, H.; Gao, G.-P.; Kelm, S.; Benie, A. J.; Hricovini, M.; Peters, T.; Ernst, B. ChemBioChem 2008, 9, 2941-2945. doi:10.1002/cbic.200800458

92. Kerzmann, A.; Fuhrmann, J.; Kohlbacher, O.; Neumann, D. J. Chem. Inf. Model. 2008, 48, 1616-1625. doi:10.1021/ci800103u

93. Kerzmann, A.; Neumann, D.; Kohlbacher, O. J. Chem. Inf. Model. 2006, 46, 1635-1642. doi:10.1021/ci050422y

94. Case, D. A.; Cheatham, T. E., III; Darden, T.; Gohlke, H.; Luo, R.; Merz, K. M., Jr.; Onufriev, A.; Simmerling, C.; Wang, B.; Woods, R. J. J. Comput. Chem. 2005, 26, 1668-1688. doi:10.1002/jcc.20290

95. Case, D. A.; Darden, T. A.; Cheatham, T. E.; Simmerling, C. L.; Wang, J.; Duke, R. E.; Luo, R.; Walker, R. C.; Zhang, W.; Merz, K. M.; Roberts, B. P.; Wang, B.; Hayik, S.; Roitberg, A.; Seabra, G.; Kolossváry, I.; Wong, K. F.; Paesani, F.; Vanicek, J.; Liu, J.; Wu, X.; Brozell, S. R.; Steinbrecher, T.; Gohlke, H.; Cai, Q.; Ye, X.; Wang, J.; Hsieh, M.-J.; Cui, G.; Roe, D. R.; Mathews, D. H.; Seetin, M. G.; Sagui, C.; Babin, V.; Luchko, T.; Gusarov, S.; Kovalenko, A.; Kollman, P. A. AMBER 11; University of California: San Francisco, 2010.

96. Jo, S.; Song, K. C.; Desaire, H.; MacKerell, A. D., Jr.; Im, W. J. Comput. Chem. 2011, 32, 3135-3141. doi:10.1002/jcc.21886

97. Brooks, B. R.; Brooks, C. L., III; Mackerell, A. D., Jr.; Nilsson, L.; Petrella, R. J.; Roux, B.; Won, Y.; Archontis, G.; Bartels, C.; Boresch, S.; Caflisch, A.; Caves, L.; Cui, Q.; Dinner, A. R.; Feig, M.; Fischer, S.; Gao, J.; Hodoscek, M.; Im, W.; Kuczera, K.; Lazaridis, T.; Ma, J.; Ovchinnikov, V.; Paci, E.; Pastor, R. W.; Post, C. B.; Pu, J. Z.; Schaefer, M.; Tidor, B.; Venable, R. M.; Woodcock, H. L.; Wu, X.; Yang, W.; York, D. M.; Karplus, M. J. Comput. Chem. 2009, 30, 1545-1614. doi:10.1002/jcc.21287

98. Bohne-Lang, A.; von der Lieth, C.-W. Nucleic Acids Res. 2005, 33 (Suppl. 2), W214-W219. doi:10.1093/nar/gki385

99. Kirschner, K. N.; Yongye, A. B.; Tschampel, S. M.; González-Outeiriño, J.; Daniels, C. R.; Foley, B. L.; Woods, R. J. J. Comput. Chem. 2008, 29, 622-655. doi:10.1002/jcc.20820

100.Woods, R. J.; Tessier, M. B. Curr. Opin. Struct. Biol. 2010, 20, 575-583. doi:10.1016/j.sbi.2010.07.005

101.Sapay, N.; Cabannes, E.; Petitou, M.; Imberty, A. Glycobiology 2011, 21, 1181-1193. doi:10.1093/glycob/cwr052

102. Jo, S.; Kim, T.; Iyer, V. G.; Im, W. J. Comput. Chem. 2008, 29, 1859-1865. doi:10.1002/jcc.20945

103. Eisenhaber, B.; Bork, P.; Eisenhaber, F. J. Mol. Biol. 1999, 292, 741-758. doi:10.1006/jmbi.1999.3069

104. Julenius, K.; Mølgaard, A.; Gupta, R.; Brunak, S. Glycobiology 2005, 15, 153-164. doi:10.1093/glycob/cwh151 
105. Julenius, K. Glycobiology 2007, 17, 868-876. doi:10.1093/glycob/cwm050

106. Johansen, M. B.; Kiemer, L.; Brunak, S. Glycobiology 2006, 16, 844-853. doi:10.1093/glycob/cwl009

107. Gupta, R.; Jung, E.; Gooley, A. A.; Williams, K. L.; Brunak, S.; Hansen, J. Glycobiology 1999, 9, 1009-1022. doi:10.1093/glycob/9.10.1009

108. Gupta, R.; Brunak, S. Pac. Symp. Biocomput. 2002, 310-322. 109.Chen, Y.-Z.; Tang, Y.-R.; Sheng, Z.-Y.; Zhang, Z. BMC Bioinf. 2008, 9, No. 101. doi:10.1186/1471-2105-9-101

110.Caragea, C.; Sinapov, J.; Silvescu, A.; Dobbs, D.; Honavar, V. BMC Bioinf. 2007, 8, No. 438. doi:10.1186/1471-2105-8-438

111. Fankhauser, N.; Mäser, P. Bioinformatics 2005, 21, 1846-1852. doi:10.1093/bioinformatics/bti299

112. Hamby, S. E.; Hirst, J. D. BMC Bioinf. 2008, 9, No. 500. doi:10.1186/1471-2105-9-500

113. Morris, G. M.; Huey, R.; Lindstrom, W.; Sanner, M. F.; Belew, R. K.; Goodsell, D. S.; Olson, A. J. J. Comput. Chem. 2009, 30, 2785-2791. doi:10.1002/jcc.21256

114.Bhunia, A.; Jayalakshmi, V.; Benie, A. J.; Schuster, O.; Kelm, S.; Rama Krishna, N.; Peters, T. Carbohydr. Res. 2004, 339, 259-267. doi:10.1016/j.carres.2003.09.021

115.Kuntothom, T.; Raab, M.; Tvaroška, I.; Fort, S.; Pengthaisong, S.; Cañada, J.; Calle, L.; Jiménez-Barbero, J.; Ketudat Cairns, J. R.; Hrmova, M. Biochemistry 2010, 49, 8779-8793. doi:10.1021/bi101112c

116.DeMarco, M. L.; Woods, R. J.; Prestegard, J. H.; Tian, F. J. Am. Chem. Soc. 2010, 132, 1334-1338. doi:10.1021/ja907518x

117.Kogelberg, H.; Frenkiel, T. A.; Homans, S. W.; Lubineau, A.; Feizi, T. Biochemistry 1996, 35, 1954-1964. doi:10.1021/bi9521598

118. Morando, M. A.; Nurisso, A.; Grenouillat, N.; Vauzeilles, B.; Beau, J.-M.; Cañada, F. J.; Jiménez-Barbero, J.; Imberty, A Glycobiology 2011, 21, 824-833. doi:10.1093/glycob/cwr014

119.Säwén, E.; Stevensson, B.; Östervall, J.; Maliniak, A.; Widmalm, G. J. Phys. Chem. B 2011, 115, 7109-7121. doi:10.1021/jp2017105

120.Tessier, M. B.; DeMarco, M. L.; Yongye, A. B.; Woods, R. J. Mol. Simul. 2008, 34, 349-363. doi:10.1080/08927020701710890

121. Fadda, E.; Woods, R. J. Drug Discovery Today 2010, 15, 596-609. doi:10.1016/j.drudis.2010.06.001

122. Tschampel, S. M.; Kennerty, M. R.; Woods, R. J. J. Chem. Theory Comput. 2007, 3, 1721-1733. doi:10.1021/ct700046j

123.Van Der Spoel, D.; Lindahl, E.; Hess, B.; Groenhof, G.; Mark, A. E.; Berendsen, H. J. C. J. Comput. Chem. 2005, 26, 1701-1718. doi:10.1002/jcc.20291

124.Guerrini, M.; Beccati, D.; Shriver, Z.; Naggi, A.; Viswanathan, K.; Bisio, A.; Capila, I.; Lansing, J. C.; Guglieri, S.; Fraser, B.; Al-Hakim, A.; Gunay, N. S.; Zhang, Z.; Robinson, L.; Buhse, L.; Nasr, M.; Woodcock, J.; Langer, R.; Venkataraman, G.; Linhardt, R. J.; Casu, B.; Torri, G.; Sasisekharan, R. Nat. Biotechnol. 2008, 26, 669-675. doi:10.1038/nbt1407

125.Beyer, T.; Diehl, B.; Randel, G.; Humpfer, E.; Schäfer, H.; Spraul, M.; Schollmayer, C.; Holzgrabe, U. J. Pharm. Biomed. Anal. 2008, 48, 13-19. doi:10.1016/j.jpba.2008.06.014

126.Alban, S.; Lühn, S.; Schiemann, S.; Beyer, T.; Norwig, J.; Schilling, C.; Rädler, O.; Wolf, B.; Matz, M.; Baumann, K.; Holzgrabe, U. Anal. Bioanal. Chem. 2011, 399, 605-620. doi:10.1007/s00216-010-4169-7

127.Goldberg, D.; Bern, M.; Parry, S.; Sutton-Smith, M.; Panico, M.; Morris, H. R.; Dell, A. J. Proteome Res. 2007, 6, 3995-4005. doi:10.1021/pr070239f
128. Goldberg, D.; Sutton-Smith, M.; Paulson, J.; Dell, A. Proteomics 2005, 5, 865-875. doi:10.1002/pmic.200401071

129. Tang, H.; Mechref, Y.; Novotny, M. V. Bioinformatics 2005, 21 (Suppl. 1), i431-i439. doi:10.1093/bioinformatics/bti1038

130.Lohmann, K. K.; von der Lieth, C.-W. Proteomics 2003, 3, 2028-2035. doi:10.1002/pmic.200300505

131. Ozohanics, O.; Krenyacz, J.; Ludányi, K.; Pollreisz, F.; Vékey, K.; Drahos, L. Rapid Commun. Mass Spectrom. 2008, 22, 3245-3254. doi:10.1002/rcm.3731

132. Cooper, C. A.; Gasteiger, E.; Packer, N. H. Proteomics 2001, 1, 340-349. doi:10.1002/1615-9861(200102)1:2<340::AID-PROT340>3.0.CO;2-B

133. Maass, K.; Ranzinger, R.; Geyer, H.; von der Lieth, C.-W.; Geyer, R. Proteomics 2007, 7, 4435-4444. doi:10.1002/pmic.200700253

134.Irungu, J.; Go, E. P.; Dalpathado, D. S.; Desaire, H. Anal. Chem. 2007, 79, 3065-3074. doi:10.1021/ac062100e

135.Pompach, P.; Chandler, K. B.; Lan, R.; Edwards, N.; Goldman, R. J. Proteome Res. 2012, 11, 1728-1740. doi:10.1021/pr201183w

136.Lohmann, K. K.; von der Lieth, C.-W. Nucleic Acids Res. 2004, 32 (Suppl. 2), W261-W266. doi:10.1093/nar/gkh392

137.Joshi, H. J.; Harrison, M. J.; Schulz, B. L.; Cooper, C. A.; Packer, N. H.; Karlsson, N. G. Proteomics 2004, 4, 1650-1664. doi:10.1002/pmic.200300784

138.Ceroni, A.; Maass, K.; Geyer, H.; Geyer, R.; Dell, A.; Haslam, S. M. J. Proteome Res. 2008, 7, 1650-1659. doi:10.1021/pr7008252

139. Gao, H. Y. J. Am. Soc. Mass Spectrom. 2009, 20, 1739-1742. doi:10.1016/j.jasms.2009.05.012

140.Zhang, H.; Singh, S.; Reinhold, V. N. Anal. Chem. 2005, 77, 6263-6270. doi:10.1021/ac050725r

141.Lapadula, A. J.; Hatcher, P. J.; Hanneman, A. J.; Ashline, D. J.; Zhang, H.; Reinhold, V. N. Anal. Chem. 2005, 77, 6271-6279. doi:10.1021/ac050726j

142. Gaucher, S. P.; Morrow, J.; Leary, J. A. Anal. Chem. 2000, 72 , 2331-2336. doi:10.1021/ac000096f

143.Ethier, M.; Saba, J. A.; Spearman, M.; Krokhin, O.; Butler, M.; Ens, W.; Standing, K. G.; Perreault, H. Rapid Commun. Mass Spectrom. 2003, 17, 2713-2720. doi:10.1002/rcm.1252

144.Lundborg, M.; Widmalm, G. Anal. Chem. 2011, 83, 1514-1517. doi:10.1021/ac1032534

145.Jansson, P.-E.; Stenutz, R.; Widmalm, G. Carbohydr. Res. 2006, 341, 1003-1010. doi:10.1016/j.carres.2006.02.034

146.Vranken, W. F.; Boucher, W.; Stevens, T. J.; Fogh, R. H.; Pajon, A.; Llinas, M.; Ulrich, E. L.; Markley, J. L.; Ionides, J.; Laue, E. D. Proteins 2005, 59, 687-696. doi:10.1002/prot.20449

147.Loß, A.; Stenutz, R.; Schwarzer, E.; von der Lieth, C.-W. Nucleic Acids Res. 2006, 34 (Suppl. 2), W733-W737. doi:10.1093/nar/gkl265

148. Takahashi, N.; Kato, K. Trends Glycosci Glycotechnol. 2003, 15, 235-251. doi:10.4052/tigg.15.235

149. Packer, N. H.; Karlsson, N. G. Glycomic Mass Spectrometric Analysis and Data Interpretation Tools. In Bioinformatics for Glycobiology and Glycomics - an Introduction; von der Lieth, C.-W.; Lütteke, T.; Frank, M., Eds.; Wiley \& Sons: Chichester, UK, 2009; pp 223-256.

150. Maass, K.; Ceroni, A. Software Tools for Semi-automatic Interpretation of Mass Spectra of Glycans. In Bioinformatics for Glycobiology and Glycomics - an Introduction; von der Lieth, C.-W.; Lütteke, T.; Frank, M., Eds.; Wiley \& Sons: Chichester, UK, 2009; pp 257-268. 
151.Fogh, R. H.; Vranken, W. F.; Boucher, W.; Stevens, T. J.; Laue, E. D. J. Biomol. NMR 2006, 36, 147-155. doi:10.1007/s10858-006-9076-z 152. Jansson, P. E.; Kenne, L.; Widmalm, G. J. Chem. Inf. Comput. Sci. 1991, 31, 508-516. doi:10.1021/ci00004a013

153.Stenutz, R.; Jansson, P.-E.; Widmalm, G. Carbohydr. Res. 1998, 306, 11-17. doi:10.1016/S0008-6215(97)10047-7

154.Lundborg, M.; Fontana, C.; Widmalm, G. Biomacromolecules 2011, 12, 3851-3855. doi:10.1021/bm201169y

\section{License and Terms}

This is an Open Access article under the terms of the Creative Commons Attribution License

(http://creativecommons.org/licenses/by/2.0), which permits unrestricted use, distribution, and reproduction in any medium, provided the original work is properly cited.

The license is subject to the Beilstein Journal of Organic Chemistry terms and conditions:

(http://www.beilstein-journals.org/bjoc)

The definitive version of this article is the electronic one which can be found at: doi:10.3762/bjoc. 8.104 